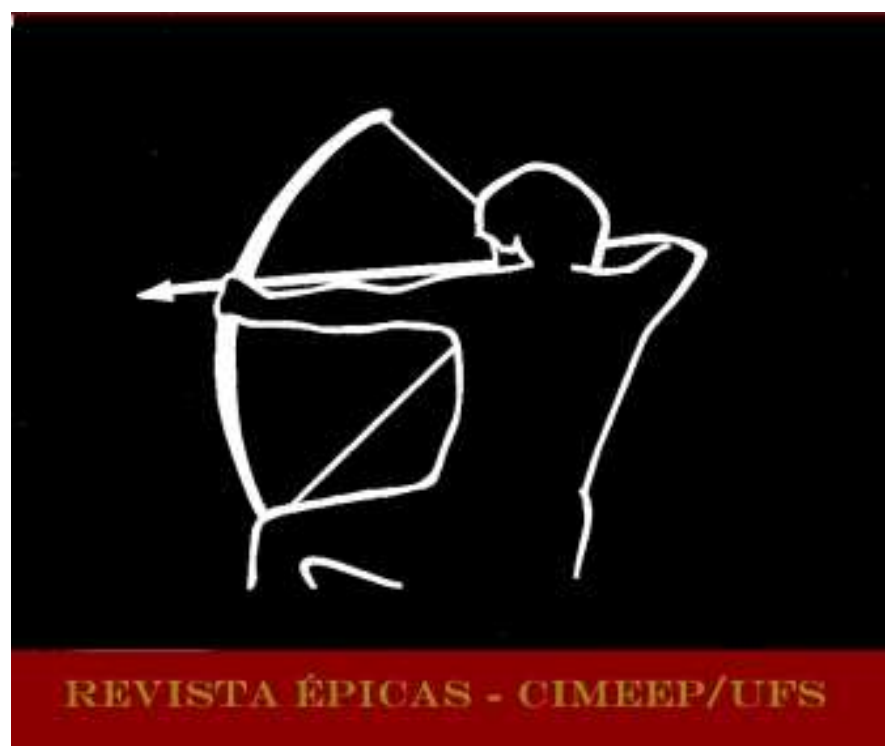

SANTOS, João Victor Rodrigues. A busca pela eternidade: aproximações entre Murilo mendes e Dante Alighieri. In: Revista Épicas. Ano 5, Número Especial 4, Mar 2021, p. 132-149. ISSN 2527080X. DOI: http://dx.doi.org/10.47044/2527-080X.2021vNE4.132149

\title{
A BUSCA PELA ETERNIDADE: APROXIMAÇÕES ENTRE MURILO MENDES E DANTE ALIGHIERI ${ }^{1}$ THE SEARCH FOR ETERNITY: APPROACHES BETWEEN MURILO MENDES AND DANTE ALIGHIERI
}

\author{
João Victor Rodrigues Santos ${ }^{2}$ \\ Universidade Federal de Sergipe - UFS
}

RESUMO: Com a intenção de estudar as relações entre Ser e Eternidade, o presente estudo buscou aproximar As metamorfoses (2002), de Murilo Mendes, e A divina comédia (2017), de Dante Alighieri. Com o apoio de textos como os de Carvalhal (1986) e Nitrini (2015), utilizamos da Literatura Comparada como referencial teórico para podermos cotejar os versos líricos de um e os épicos de outro, a fim de analisar como foi o processo de recepção da obra italiana pela brasileira. A partir de Lucchesi (2013), para quem a comédia dantesca é vista de maneira diluída em poetas brasileiros do século XX, empreendemos a apreciação dos versos murilianos e levantamos hipóteses acerca de como estes se associariam aos italianos por meio de relações temáticas e sonoro-imagéticas. Com isso, pudemos concluir que As metamorfoses absorve traços de $A$ divina comédia e dela se diferencia, conseguindo manter o equilíbrio entre influência e originalidade.

Palavras-chave: A divina comédia. Eternidade. Literatura Comparada. Poesia brasileira.

ABSTRACT: With the intention of studying the relationship between Being and Eternity, the present study sought to bring together As metamorfoses, by Murilo Mendes, and The divine comedy, by Dante Alighieri. With the support of texts such as those by Carvalhal (1986) and Nitrini (2015), we used Comparative Literature as a theoretical framework in order to compare the lyric verses of one and the epics verses of the other, in order to analyze how it was the process

\footnotetext{
${ }^{1}$ Este texto é fruto do desenvolvimento do plano de trabalho "Ressonância de $A$ divina comédia no Brasil do século XX" (pertencente ao projeto de iniciação científica "Ressonâncias de $A$ divina comédia no Brasil"), orientado pelo Prof. Dr. Alexandre de Melo Andrade, no período compreendido entre agosto de 2019 e julho de 2020.

2 Graduando em Letras Português pela Universidade Federal de Sergipe. E-mail: jvrs180499@gmail.com. ORCID: https://orcid.org/0000-0001-5064-9949.
} 
of receiving the Italian work by the Brazilian. Based on Lucchesi (2013), for whom the dantesque comedy is seen in a diluted way in 20th century Brazilian poets, we undertook the appreciation of murilian verses and raised hypotheses about how they would associate with Italians through thematic and sonorous relationships imagery. With that, we were able to conclude that As metamorfoses absorbs traces of The divine comedy and is different from it, managing to maintain the balance between influence and originality.

Palavras-chave: The divine comedy. Eternity. Comparative Literature. Brazilian poetry.

\section{Introdução}

A produção poética brasileira do século XX caracteriza-se, além do mais, por tratar de questões atinentes às angústias do eu-lírico. A partir da influência das vanguardas europeias, por exemplo, o manejo com o verbo dinamizou-se e as deformidades que rondam os seres empíricos passaram a ser transpostas para o papel por meio de versos que metaforizam, em suas constituições, estados de espírito externos a eles. Versos brancos e livres irmanam-se com produções de perícia métrica e evidente musicalidade para exprimirem o quão angustiante tornou-se a vida. Nesse contexto, os versificadores empreendem uma jornada em que se busca o ensimesmamento e a exteriorização de emoções e experiências, simultânea e paradoxalmente.

Os martírios com os quais se convivem fazem com que muitos poetas tratem de ressignificar seus caóticos contextos contemporâneos, sejam eles históricos e/ou culturais em busca da harmonia perdida e de uma unicidade passada ou idealizada. O retorno à tradição estabelece-se como referencial de tempo e experiências harmônicas e os poetas procuram, a partir dele, reorganizar e melhor compreender seus contextos exteriores imediatos, bem como poder contribuir para uma espécie de lapidação sociocultural.

Diante disso, neste escrito buscamos aproximar um poeta brasileiro do século XX, Murilo Mendes, e um poeta eternizado pela tradição literária mundial, Dante Alighieri. Para tanto, cotejaremos As metamorfoses (2002) e A divina comédia (2017). Resguardadas as diferenças de gênero entre a obra lírica e a épica, este procedimento visa analisar e compreender como se deu a recepção da obra italiana nos versos brasileiros. Assim, visitaremos o campo de estudo da Literatura Comparada para podermos compreender noções como as de absorção, influência, intermediário, originalidade e recepção. Como justificativa para tal empresa, apontamos a carência de estudos comparativos entre a épica dantesca e a literatura brasileira de modo amplo, não somente restrita ao campo da poesia lírica. Consequentemente, espera-se poder contribuir com a fortuna crítica de ambos os poetas.

\section{Metodologia}

Como tratamos de, por meio da literatura comparada, aproximar os escritos de Mendes e Alighieiri, é importante que delimitemos certos conceitos como, por exemplo, influência e originalidade. Nitrini (2015) apresenta duas acepções diferentes para o conceito de influência. Segundo a estudiosa, 
A primeira, a mais corrente, é a que indica a soma de relações de contato de qualquer espécie, que se pode estabelecer entre um emissor e um receptor. [...] A segunda acepção é de ordem qualitativa. Influência é o "resultado artístico autônomo de uma relação de contato", entendendose por contato o conhecimento direto ou indireto de uma fonte por um autor (NITRINI, 2015, p. 127 , aspas da autora).

Com isso, pelo fato de não encontrarmos traços de citações diretas que indiquem somas de contato explícito entre o emissor ( $A$ divina comédia) e o receptor (As metamorfoses), adotamos aqui a ideia de influência como algo de ordem qualitativa. Ou seja, intuímos que Murilo Mendes, direta ou indiretamente, teve acesso ao texto dantesco e, fruto deste contato, o emissor influenciou/contribuiu para a construção do receptor. Estas relações de contato acabam por carregar consigo alguns questionamentos correspondentes à ideia da originalidade, tais como: até que ponto o receptor bebe no emissor? Como se estabelece a originalidade de quem recebe? Diante de interrogações como estas, cabe-nos esclarecer qual é a ideia de originalidade com a qual trabalharemos.

Falar de originalidade reclama falar, também, de plágio. Muitas são as questões e as polêmicas que envolvem as querelas entre os limites de ambos. Ao abordar o entendimento de Paul Valéry acerca de assuntos pertinentes à Literatura Comparada, Nitrini comenta a metáfora do pensador francês da alimentação. Por meio de tal analogia, podemos vir a compreender o que configuraria o original e o plágio, resguardando, logicamente, as características hermenêuticas que nos fazem formular tais conceitos. Diz-nos a estudiosa que, segundo Valéry,

"Nada mais original, nada mais próprio do que nutrir-se dos outros. Mas é preciso digeri-los. O leão
é feito de carneiro assimilado". A originalidade é, pois, um caso de assimilação, "caso de
estômago", segundo expressão do próprio Valéry. A qualidade da digestão "da substância dos
outros" é o que define os limites entre a originalidade e o plágio: "Plagiário é aquele que digeriu
mal a substância dos outros: torna seus pedaços reconhecíveis" (NITRINI, 2015, p. 134-135, aspas
da autora, grifo nosso).

Com efeito, o original seria aquele que absorveria completamente os textos lidos e conseguiria deixar transparecer sua marca própria, sua individualidade. Seguindo o caminho contrário, o plagiário configurarse-ia como aquele que não detém de tanta "qualidade" na digestão de determinado(s) texto(s) e, por conseguinte, acaba por deixar com que estes sejam vistos e materializem sua intenção (?) de buscar ser original. Ao falar sobre individualidade, talvez seja importante destacar a ideia de Bakhtin, para quem nada seria plenamente individual, posto que os sujeitos constituem-se por meio de (inter)relações mantidas entre o eu, os outros e o mundo exterior.

Por fim, nos interessa informar quais são as noções de emissor e receptor com as quais trabalharemos. Segundo Nitrini, ao abordar a literatura comparada de linha francesa, num processo de passagem de influências, o emissor constitui-se como uma espécie de ponto de partida; e o receptor, como ponto de chegada. Sintetizando as ideias abordadas, ao nos referirmos aos métodos de estudo que envolvem elementos como emissor, receptor, influência e originalidade, Nitrini diz que 
Caso a observação seja feita do ponto de vista do emissor, haverá dois tipos de estudos: o do sucesso de uma obra, de um escritor, de um gênero, de uma literatura inteira num país estrangeiro e o da influência de um escritor, de uma obra, de um gênero sobre um outro escritor, uma obra estrangeira e assim por diante. Se a observação for feita do ponto de vista do receptor, trata-se do estudo das fontes de um escritor ou de uma obra. Uma outra possibilidade de estudo é o dos intermediários que facilitaram a transmissão das influências, tais como indivíduos, meios sociais (cenáculos e salões literários), críticas (jornais e revistas), traduções e tradutores (NITRINI, 2015, p. 33).

Destacamos que, metodologicamente, o presente escrito busca inserir-se no campo da literatura comparada a partir da observação de influências sob a ótica do receptor. Com isso, para atingirmos os objetivos propostos, cotejaremos versos e poemas de As metamorfoses (2002) com versos de $A$ divina comédia (2017), utilizando-nos de ideias como a da Desleitura e da Angústia da influência, de Harold Bloom e as noções de originalidade e absorção de Paul Valéry, conforme citado acima.

\section{A épica fundante da Literatura Italiana e o poeta das possibilidades}

O épico dantesco, com seus 14.233 versos e sua divisão em três livros e cem cantos - Inferno com trinta e quatro cantos, Purgatório e Paraíso com trinta e três cantos cada - foi o responsável por alçar Dante Alighieri ao patamar dos maiores escritores do mundo. Otto Maria Carpeaux, em "Lendo e relendo Dante", texto prefaciador de uma das mais recentes edições de $A$ divina comédia no Brasil, diz-nos que "Dante criou a língua literária italiana. Dante criou a própria literatura italiana. A primeira grande obra da literatura italiana é, ao mesmo tempo, a maior obra da literatura italiana" (CARPEAUX, 2017, p. 7). Tal é a magnitude da comédia dantesca que o próprio estudioso classifica-a como um poema "sui generis", isto é, um texto que apesar de apresentar características que gravitam entre diferentes gêneros (épico, lírico e dramático), não se enquadra efetivamente em nenhum deles, mas possui seu próprio tipo. A partir disto, poderíamos questionar seu enquadramento no rol de textos épicos. Assinalamos, entretanto, que, além de toda uma tradição que considera e nomeia $A$ divina comédia como uma epopeia, baseamo-nos também nos dizeres de Moisés (2012), para quem a poesia épica é de

[...] alcance universalista, gravita em torno do sentimento e do conhecimento simultâneo da perfeição e harmonia do Cosmos. [...] o enigma da harmonia universal, manifesto por meio de um jogo contínuo de contrastes (o claro e o escuro, o dia e a noite, o contingente e o "eterno", o relativo e o absoluto, etc.), é que atrai o poeta épico [...] (MOISÉS, 2012, p. 200-201, aspas do autor).

Aspectos como o jogo de claro e escuro, por exemplo, refletem-se evidentemente na obra dantesca. A escuridão, aliada às pungentes punições dos condenados, é o que acompanha o poeta-personagem e seu guia pelo Inferno, assim como é por caminhos ladrilhados por forte luminosidade que Dante, junto de Beatriz e São Bernardo, ascende aos círculos paradisíacos. Diante do apelo do florentino aos órgãos do sentido - 
principalmente visão e audição -, podemos reforçar o dito de Moisés e acrescentar à relação claro-escuro a distinção sonora que acompanha a épica dantesca: os ais e as lamúrias são também constituintes da escuridão infernal e apresentam-se como elementos diametralmente opostos aos cantos de regozijo entoados com cada vez mais intensidade no Paraíso, que acentuam a luminosidade do espaço.

Moisés fala ainda que textos épicos trazem, em seu cerne, temas tidos como grandiosos que se exprimem não somente em sua forma, mas também na maneira como são abordados. "O sublime, o grandioso, revela-se tanto no conteúdo (os temas, as figuras, etc.) como na forma (a grandiloquência da diç̧ão, os metros longos, marcialmente escandidos, etc.) como na escolha dos acontecimentos e na magnitude dramática em que decorrem" (MOISÉS, 2012, p. 201). Em toda a jornada do poeta florentino percebemos a intensidade dramática com que os acontecimentos são expressos e a própria grandeza temática do conteúdo de seu texto. Seja através dos sentimentos de dor que invadem o poeta-personagem ao lidar com cenas de terror e angústia no Inferno, seja no esforço da íngreme subida pelo monte Purgatório ou mesmo no efeito sublime que o preenche ao adentrar aos céus do Paraíso, a intensidade dramática é algo que percorre toda a épica dantesca, desde o encontro com a loba, o leão e a pantera, na selva escura, até a visão da Rosa Mística, no Paraíso. Além disso, retomando a magnitude temática da obra, afora o aspecto universal da Morte, que é um tema uniforme nos versos da comédia dantesca, podemos assinalar a própria experiência do poeta em percorrer e viver mundos somente imaginados e, com isso, poder elevar-se espiritualmente e reconectar-se com o Cosmos. Por fim, consideremos também, como elementos que reafirmam A divina comédia enquanto texto épico, sua estruturação: a escrita em versos, o aspecto narrativo, a divisão em cantos etc.

Para Lucchesi (2013), A divina comédia “[...] mais que simples manancial de episódios ou de citações, é essencialmente um potencial aberto, uma visão de mundo fundadora, lá onde o verso coincide com o universo" (LUCCHESI, 2013, p. 107). É interessante notarmos, em tal passagem, a ideia de a obra ser o lugar de amalgamento e de coincidência entre o verso - podendo este ser encarado como metonímia do processo poético de criação - e o universo, isto é, aquilo que seria uni, que seria uno consigo mesmo, o que nos remete ao Hierarca primeiro, Deus. Ou seja, $A$ divina comédia poderia ser encarada como uma jornada em busca pela Causa primeira, pelo Uno. Imagina-se, pois, que tal desejo de avanço, de um "ir além" do conhecido, possua em si o prisma de uma insaciabilidade, de uma insatisfação com a finitude terrestre. Estas últimas ideias podem ser apontadas, por exemplo, no poema "A chave", de Murilo Mendes, que será abordado mais adiante. Tendo em vista a ideia de que a comédia dantesca seria uma jornada em busca de conhecer-se, de elevar-se, Lucchesi diz-nos que

[...] a Divina comédia deve ser entendida como uma viagem para Deus, constituída por uma poética da conversão e uma poética da profecia. Dante se converte e nos mostra todos os males da humanidade em queda, o seu resgate e o caminho iluminado pelo Sol, com análises de todo o seu tempo, com o passado e o futuro, como se diante de Deus invocasse a justiça que injustamente exilado não encontrava na Terra (LUCCHESI, 2013, p. 12). 
Diante de todas estas características e importância, $A$ divina comédia figura, há séculos, como um dos mais conhecidos e renomados livros do mundo. $\mathrm{O}$ escrito de Dante alçou-se por si mesmo ao patamar de obra atemporal e inesgotável de leituras. Com efeito, não demorou muito e ela chegou até terras brasileiras. As traduções da Comédia chegaram até nós de maneiras diferentes. Há casos de traduções parciais e integrais. Podemos citar desde Machado de Assis, que traduziu o canto XXV do Inferno, em 1874, passar pelo Barão da Vila da Barra, que, segundo Sterzi (2008), foi o responsável pela primeira tradução integral da obra, até chegarmos a Cristiano Martins, Ítalo Eugênio Mauro, Graça Aranha e José Xavier Pinheiro (tradução da qual retiramos os versos utilizados mais adiante), dentre outros.

Além mesmo dos resquícios dantescos no Brasil em forma de traduções integrais ou parciais, ou de estudos desenvolvidos a partir de sua obra, principalmente de sua Comédia, a produção literária brasileira apresenta também alguns aspectos que sofreram influências do poema sacro - seja em forma da transposição de episódios, de citações, personagens, ambientes etc. Tais traços de importação dantesca podem ser vistos de maneira direta, isto é, em forma de evidências na própria materialidade textual, por meio de citações diretas ou do uso de epígrafes, como acontece em alguns poemas de Álvares de Azevedo e na prosa machadiana, por exemplo. Além das evidências diretas, $A$ divina comédia mostra-se também como um constituinte intrínseco em algumas construções da literatura brasileira. Segundo Marco Lucchesi,

A sombra luminosa do Florentino merece cuidados especiais, com suas projeções tentaculares, na grande poesia do século XX, como na obra de Murilo Mendes, Jorge de Lima, João Cabral de Melo Neto e Carlos Drummond de Andrade. Um Dante menos visível, menos citado e mais absorvido (LUCCHESI, 2013, p. 105).

Diante das relações mantidas entre Dante Alighieri e a literatura brasileira, focaremos, nas linhas seguintes, em abordar como se deu a recepção de Dante por Murilo Mendes, nos versos de As metamorfoses (2002).

Mineiro de Juiz de Fora, Mendes destaca-se como um expoente poeta e também prosador brasileiro do século XX. Segundo Eva Pereira (2009), podemos dizer que sua obra passou por três períodos distintos: um primeiro de cunho modernista e nacionalista; outro com uma maior ascendência espiritualista e surrealista; e também aquele que se refere aos seus últimos textos, onde ele preocupou-se com escritos de ordem mais classicizantes, concretistas.

O poeta, por vezes, utiliza-se de cenas cotidianas e banais para incitar a reflexão sobre a vida, o mundo, a totalidade das coisas. Não só os temas cotidianos como também a própria apreensão e utilização de temas religiosos faz com que a poesia muriliana seja tida como uma meta-poesia, que seu caráter religioso seja tido como uma espécie meta-religiosidade, que sua produção poética, embebida em metafísica, seja tida como uma espécie de meio pelo qual o eu-lírico busca transfigurar-se e transfigurar o mundo para ir além do conhecido, para buscar a possibilidade de unir-se ao inteligível, à Unidade de tudo, a Deus. Segundo Pereira, 
[...] ao buscar ser fiel àquela espécie de tripla necessidade [...] - meta-poesia, meta-religião e metafísica -, a poesia de Murilo Mendes parece operar a partir de uma mesma metodologia, a metamorfose, tanto em relação ao discurso em seu substrato semântico quanto em relação ao discurso em seu substrato fônico ou mesmo morfo-sintático (PEREIRA, 2009, p. 251).

Essa união de opostos, onde, de um lado, estão temas cotidianos e, de outro, ideais sublimes, aponta para o aspecto universalista preconizado pelo poeta. É universal, pois mistura os mais diferentes temas com ideais que atingem a crença de cada ser: seja religião, seja mito, seja até mesmo a tensão entre o crer e o não crer. É universal, também, porque os poemas são metamórficos, não possuem forma específica, são líquidos e adequam-se aos infinitamente variáveis recipientes que são os leitores. Murilo Mendes, por meio de uma poesia-nuvem - imagem tão presente em As metamorfoses -, que é, mas não se pode precisar o que ela vem a ser, une o caos da guerra, por exemplo, com a busca incessante por um ideal talvez utópico. No entanto, a grande questão não é se o poeta alcançará o Todo, o Absoluto. O modus operandi de As metamorfoses parece apontar para o fato de que o poeta pode alcançar o que busca, ou pelo menos pensa que pode.

Arriscamo-nos, com efeito, a dizer que a poesia de Mendes é uma poesia da possibilidade. Tal aspecto pode ser visto, por exemplo, na vanguarda surreal, que brinca e molda aquilo que é tido como já conhecido, já apreendido. Assim como os surrealistas, Murilo Mendes ultrapassa o limite do real e busca aquilo que não se é pensado como possível. Vale a pena relacionar esse caráter extramundano do poeta com o que é dito por Agamben (2009) em "O que é o contemporâneo?", para quem aquele que é contemporâneo ao seu tempo é aquele que é capaz de perceber as fissuras que nele existem e apontá-las. Não necessariamente esses apontamentos precisariam ir em direção a uma poesia engajada com o exterior do poeta, com o social, mas poderiam ser vistos como pequenas partículas de combustão que fazem o poeta ensimesmar-se e ao mesmo tempo querer ultrapassar-se, querer empreender a busca pelo Uno.

Em As metamorfoses, a ideia da ressonância dantesca é algo mais intrínseco, mais "digerido", relacionado com a ideia de Paul Valéry. Não há ou não foram percebidos caminhos que possam indicar referências diretas entre a obra e A divina comédia. Há uma ou outra referência a certo "inferno", mas nada com que se possa precisar uma referência ao Inferno dantesco ou a outro mais anterior, próprio da tradição cristã. As possíveis influências digeridas, por assim dizer, são de aspectos próprios das temáticas, imagens, sensações, sons e ideias.

A jornada de Dante pode ser vista como uma busca por autoconhecimento, baseada na finitude terrena e no desejo de reconciliação entre o Ser e o Cosmos. Talvez em busca desta empresa por conhecerse, Murilo Mendes, em muitos de seus poemas, traga ideias como: insaciabilidade com o conhecido, autosuplantação do Eu, descrença no mundo, tal qual se percebe nestes versos de "Companheira": "Companheira, dou-te a alegria/ Do que nada tem a esperar do esforço humano". A alegria dita pelo eu-lírico pode ser tida como justamente a aceitação de que o mundo é finito e, por conseguinte, ele não teria mais nada que nele buscar, mas sim em algo elevado. Eva Pereira traz, em “'A carne inconformada': notas para 
uma aproximação entre Poesia e Metafísica em Murilo Mendes", uma passagem que talvez explique o ponto de partida que impulsiona o poeta para o almejado. Segundo a estudiosa,

\begin{abstract}
O susto originário, aquele que põe o ser humano em estado de suspensão, capaz de observar de "fora" os fenômenos - sendo proveniente dos momentos de tédio, de amor intenso que inclui a sexualidade ou as inquietações nos jogos com a linguagem -, prepara o homem para a tarefa "metafísica", na qual deverá buscar "a superação da physis animal na direção da história humana". Esta superação, porém, não é obtida de uma vez por todas, antes se constitui num acontecimento "sempre em curso, que decide em cada momento e em cada indivíduo sobre o humano e o animal, sobre a natureza e a história, sobre a vida e a morte". A obra de Murilo Mendes está permanentemente aludindo a essa busca de superação do animal em direção ao humano, seja a partir do acréscimo do amor espiritual ao físico em contra posição ao desejo meramente carnal [...]; seja a partir da consciência da função do tédio e da experimentação com a linguagem no afastamento do homem em relação ao mundo [...] (PEREIRA, 2009, p. 265-266, aspas da autora).
\end{abstract}

Com base nesse "susto originário", podemos imaginar que, para cumprir o propósito do conhecerse, seria preciso voltar-se a si, ensimesmar-se, tal qual o faz o célebre florentino. Dante, ao percorrer terras desesperançadas, ao ver pecados sendo purgados e ao se deparar face ao inefável luminescente que é o Empíreo, (re)conhece-se, pois vive e busca aprimorar-se. Jornada épica que, para Mendes, traduz-se em sugestões simbolistas, num jogo sinestésico de sons e imagens que busca ir muito além dos sentidos possíveis das palavras. Diz-nos Andrade que "De assinatura muriliana inconfundível, a imagem casa indissoluvelmente mito e história, atualiza o eterno com a cicatriz do tempo presente, promovendo um ideal de beleza compósito, estranho e perturbador [...]" (ANDRADE, 2002, p. 11). Diante disso, podemos deduzir que um dos caminhos seguidos pela poética muriliana, diferente daquele que parte da selva escura, envereda-se pela transubstanciação e pela integração das visões cotidianas em combinações sonoras e virtualmente imagéticas.

É com o cinzelar exploratório das unidades mínimas das palavras e suas combinações, tão bem feito por Dante, que Mendes enseja afastar-se do terreno e tentar alçar algo além, o Eterno perseguido por Alexei Bueno em Poemas gregos $(1985)^{3}$, o Uno neoplatônico de Plotino ${ }^{4}$, o Hierarca primeiro, enfim, aquilo nomeado de Deus. Conforme dito antes, assinalamos que tal tentativa não é necessariamente exitosa. Não é a certeza de se alcançar o que se busca que move o vate muriliano, pois isso não parece se configurar como uma preocupação sua. $\mathrm{O}$ que se configura como preocupante - e até assustador -, é a estaticidade. $\mathrm{O}$ temor de parar, acomodar-se e, consequentemente, ver-se sucumbir perante o mundo e o tédio é o que alimenta o autor de As metamorfoses em sua jornada tão parecida e tão diferente daquela empreendida por Dante.

É em companhia de Virgílio, Beatriz, São Bernardo e de sua terza rima que o italiano percorre seus próprios versos épicos, assim como é em companhia de si próprio, de suas metamorfoses, de seu desejo latente pelo porvir e de seus sonoros versos livres que o brasileiro procura aproximar-se da busca dantesca.

\footnotetext{
${ }^{3}$ C.f. SANTOS, J. V. R. Mitologia e realidade em Poemas gregos (1985): deuses caídos, cabisbaixos e humildes? In: Travessias interativas. São Cristóvão: Universidade Federal de Sergipe, v. 9, n. 18, p. 81-94, Maio 2019.

${ }^{4}$ C.f. PLOTINO. Tratado das Enéadas. Tradução Américo Sommerman. São Paulo: Polar Editorial, 2000.
} 
Percebamos que a jornada de Dante, a partir das ideias de reconhecimento de si, e da empesa de alcançar sua amada Beatriz, pode ser encarada como a jornada de um insaciável. O poeta, gênio criador, é posto no patamar da eterna insaciabilidade. $O$ fado daquele que poetiza o mundo é não se satisfazer. E assim o é com Dante, e assim o é com Murilo Mendes, que parecem absorver para si próprios o circular trabalho de um Sísifo pretérito.

Esta busca, este ir além ou aquém, o próprio ato de buscar num passado um referencial ou idealizar num futuro algo que conforte o eu-lírico podem servir de base para alguns comentários acerca do fazer poético do poeta mineiro. É importante destacar uma possível influência romântica que assalta os poetas modernos e pós-modernos fazendo-lhes, personagens de mundos conflituosos, buscar referenciais num tempo diferente do seu, seja este tempo um utópico futuro ou um mítico passado, assim como Murilo Mendes busca concretizar a procura pelo Uno, a partir das influências assimiladas dA divina comédia. Vale considerarmos também que, apesar de receber influências, o fazer poético muriliano não se restringe a este ou àquele estilo, pois o poeta possui a capacidade de digerir completamente aquilo que é assimilado e, com isso, exalar originalidade.

À revelia das influências recebidas, a originalidade muriliana se mantém não somente através de seu estilo, mas por meio das maneiras como trata temas universais, já trabalhados por inúmeros poetas, como o é a insaciabilidade do Ser. Tal qual acontece com Jorge de Lima, Mendes absorve e assimila as características de diferentes épocas e períodos literários e destaca-se como um dos maiores expoentes do círculo místico e mítico da segunda geração modernista brasileira. A inquietude de ultrapassar-se, somada ao estilo fortemente marcado pela estética surrealista, faz dele uma espécie de poeta das possibilidades, das metamorfoses. A poesia-nuvem produzida por Mendes, metamórfica por excelência e natureza, resultante de um processo de pleno dialogismo entre eu-lírico e eu-empírico, é o meio encontrado por ele para transcender-se metafisicamente.

De modo a concluirmos a ideia dessa necessidade de suplantação das coisas que move a lírica muriliana, vale a pena abordarmos as ideias da Angústia da influência e da Desleitura, de Harold Bloom. Para o crítico, o criar poético é conflituoso. O eu-lírico possui um incessante desejo de ser autêntico e, por consequência, traça certas batalhas com aqueles que o influenciaram/influenciam, ou seja, cria-se buscando ultrapassar (desler) aquilo de que se alimentou. Ao abordar as ideias de Bloom, Carvalhal diz que

[...] a realização do poema corresponde [...] à desvirtuação de poemas paternos a que a obra recente se filia, ansiosamente. Para ele [Bloom], o poema não é uma vitória sobre uma ansiedade, é a própria ansiedade. Por isso, cada poema é a disputa entre Édipo e Laio, a cristalização de um atrito (CARVALHAL, 1986, p. 59).

Notemos que, ao relacionar o eu-lírico criador e os poetas que o influenciam com Édipo e Laio, Bloom acaba por deixar transparecer certo determinismo no fazer poético, isto é, o eu-criador de hoje (Édipo) 
estaria destinado a fazer sucumbir e assumir o lugar do eu-criador de ontem (Laio). Tal pensamento nos leva a algumas reflexões tangentes ao próprio ato do criar poético. Este seria ficcional, autobiográfico, ou os dois? Ou seja, o fazer poético surgiria de uma experiência de mundo ou de leitura e depois entraria em conflito com ela ou seria o contrário e o estopim criativo seria justamente a leitura de outros e seu desejo de ultrapassá-los (o que também não deixa de ser um conflito), negando a plenitude das experiências individuais ou ficcionais e levando em conta um caráter harmônico entre ambas, tal como é problematizado por Combe (2010), em "A referência desdobrada: o sujeito lírico entre a ficção e a autobiografia"? Desse modo, podemos problematizar a relação que Murilo Mendes mantém com Dante. Os versos murilianos beberiam efetivamente de Dante ou seriam criações independentes de um eu-poético que conseguiu alcançar a desleitura postulada por Bloom? Pode ser verdadeira a hipótese de uma desleitura baseada na independência? Ficam as questões e, como veremos a seguir, um meio de interpretação que considera os versos de As metamorfoses como compatíveis com a possibilidade de assimilação de A divina comédia.

\section{A poesia-nuvem: uma forma de resistência}

Algumas imagens presentes nos versos dAs metamorfoses (2002) retomam, por um lado, a ideia de movimento e, de outro, de contemplação, como é o caso da nuvem, que pode ser vista como símbolo metafórico do próprio título do livro. A nuvem como algo que mantém uma relação metonímica (ou metafórica?) com o aspecto das coisas de se metamorfosear. Corroborando a relação mantida entre nuvem e transformação, temos que "a nuvem é o símbolo da metamorfose viva, não por causa de alguma de suas características, mas em virtude de seu próprio vir-a-ser" (CHEVALIER, GHEERBRANT, 1988, p. 648). Levando em conta o jogo imagético evidente nas estruturas e nos conteúdos dos poemas, podemos levantar a hipótese de que a poesia de Murilo Mendes, no referido livro, assume características de poesia-nuvem, por conta dos constantes processos de articulação e choque, criação e destruição de elementos de naturezas e campos semânticos distintos.

Além deste, a guerra é outro tema presente em As metamorfoses que nos convida a determo-nos sobre si, não só por seus efeitos no fazer poético muriliano, mas por poder ser associado à obra de Dante. Assim como em A divina comédia, o empirismo também é de grande importância para o eu-poético de Mendes, pois visão e audição são sentidos convocados constantemente em sua composição. A guerra pode ser vista a reverberar em alguns aspectos: i) sonoridade e ii) imagética.

Os sons trazidos pelo poeta ao abordar a questão da guerra são duros, fortes e carregam uma carga semântica de negatividade, tal como se pode perceber em algumas expressões retiradas de "O poeta futuro" (MENDES, 2002, p. 34): "massacre entre irmãos", "sangue espremido", "aço da sua espada" e também nos versos "O poeta futuro apontará o inferno/ Aos geradores de guerra,/ Aos que asfixiam órfãos e operários". Sons como os oclusivos (/g/, /k/, /p/, /t/, /d/), que são maioria, demonstram tal potência e a escolha de palavras como "massacre", "sangue", "inferno", "guerra" mostra-nos como ela é rodeada de negatividade. 
Em contrapartida, a negatividade se opõe a outros poemas, onde os sons correm livres, leves, plenos. Como nos versos de "A liberdade":

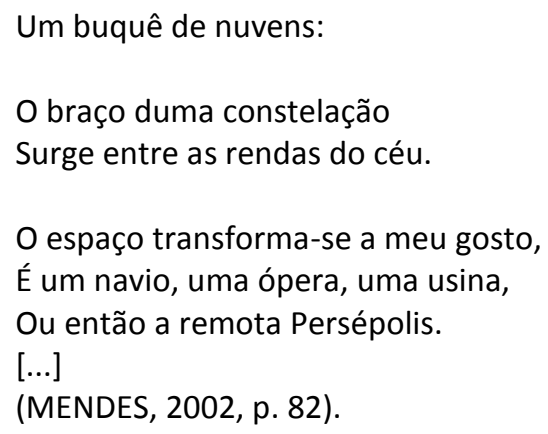

A presença de sons sibilantes e vibrantes denota a ideia de movimento, de liberdade, tal qual se apresenta no próprio título do poema. Expressões carregadas majoritariamente de sons como o sibilante /s/ e um pontual /v/ contribuem para o aspecto de leveza e de passagem que constitui tais versos. A semântica do movimento é marcada também por palavras como "nuvens", "navio" e o próprio verbo surgir, que demonstra uma ação em que se parte de certa estaticidade. O poder que o eu-lírico mostra possuir de transformar o espaço ao seu gosto, fazendo com que as coisas virem coisas tão distintas como "ópera", "usina" ou mesmo a distante "Persépolis" reflete um aspecto típico da poética muriliana: a presença de ideias surrealistas, tal como dito por Candido (1985).

Estes aspectos sonoros podem ser relacionados à jornada de Dante, onde a passagem pelos círculos infernais é carregada de forte azedume para o poeta, pois, além de ver o sofrimento dos condenados, ele ouve seus sons lamurientos, seus ais que correm os cantos infernais, suas dores, em suma. Destaque-se, em relação ao Inferno, o episódio do canto XXIV em que Dante e Virgílio se deparam com os ladrões, que são picados por horríveis víboras. Diz o poeta florentino entre os versos 76-84:

\footnotetext{
Fomos da ponte à parte, donde é claro

Que se vai ter à ribanceira oitava:

Ficou patente a cava ao meu reparo.

De serpes tal cardume se enroscava, Horríficas na infinda variedade, Que ao sangue, inda ao lembrar, terror me trava (ALIGHIERI, 2017, p. 123).
}

A presença de sons oclusivos e palavras que denotam certa negatividade, assim como nos versos citados de Mendes, se faz presente na referida passagem dantesca. Sons como /p/, /t/, /d/, /k/, /b/, /g/, ao se unirem com as expressões carregadas de uma negatividade aterrorizante como "serpes", "horríficas", "sangue", "terror", podem mostrar certa relação com a já citada potência oclusiva acompanhada da negatividade semântica, presente nos versos de "O poeta futuro". 
Ao Dante percorrer o Purgatório e o Paraíso, acontece o contrário do que é visto no Inferno: quanto mais próximo se chega do princípio primeiro, mais sonoro e luminoso se torna o ambiente. Os próprios pecadores, os iracundos, purgam suas chagas entoando cantos a Deus. Os sentidos da visão e da audição possuem imensa importância nA divina comédia, e também em As metamorfoses, tanto como algo benfazejo (no sentido de luzes e sons agradáveis, emocionantes), quanto como algo não-salutar (no sentido da guerra, das dores refletidas em ais e das próprias escuridões). Tendo em mente as ideias acerca da visão, audição e olfato, todas ligadas à ideia tanto de sofrimento, quanto de regozijo podemos retomar o que diz Lucchesi. Para ele, a visão teria um papel fundamental na jornada de Dante, pois

Não há infinito sem luz. Não há luz sem infinito. A cosmologia da Divina comédia depende essencialmente da luz. Por excesso ou por falta. Morte ou Amor. Variando a cor, a intensidade e a qualidade, a luz assume múltiplas funções no Paraíso: integra o visível ao invisível, a imagem à antiimagem, o fundo à superfície. A luz amplia a distância, revela o inusitado das formas, assinala a passagem das estrelas, organiza corais luminosos, acentua a labilidade das formas, o ritmo e o desenho (LUCCHESI, 2013, p. 83).

Além desta perspectiva ligada aos sentidos estimulados por Alighieri e por Mendes, podemos associá-los à ideia de movimento, que se reverbera também numa tentativa de autoconhecimento, autodefinição. O próprio Murilo Mendes diz em "Começo de biografia" que é

\footnotetext{
[...] o pássaro diurno e noturno,

O pássaro misto de carne e lenda,

Encarregado de levar o alimento da poesia e da música

Aos habitantes da estrada, do arranha-céu e da nuvem.

Eu sou o pássaro feito homem, que vive no meio de vós.

Eu vos forneço o alimento da catástrofe e o ritmo puro.

Trago comigo a semente de Deus... e a visão do dilúvio

(MENDES, 2002, p. 52).
}

Expressões como "pássaro diurno e noturno" e "misto de carne e lenda" podem transpassar a ideia de universalidade. Isto se corroboraria com alguns indicativos de entremeio, tais como: "estrada", "carne e lenda", "diurno e noturno". O eu-lírico se apresenta como aquele que está no meio do caminho entre a poesia e a música, entre o mundo terreno e o mundo poético. Destaque-se que este poema pode apresentar, ainda, algumas referências mais específicas em relação à comédia dantesca, isso partindo do aspecto subjetivo do texto literário.

As expressões "estrada", "arranha-céu" e "nuvem" podem ser vistas como associações à Comédia: a estrada seria o Inferno, por seu caráter essencialmente terreno; o arranha-céu representaria o monte Purgatório, por conta de sua elevação terrena; a nuvem, o Paraíso, pois é o que está acima de todos e por ser nada, por ser indefinida e mudar constantemente, tudo é, tudo pode vir a ser. Esta última ideia pode ser vista também no fato de o eu-lírico carregar "a semente de Deus", metáfora da inventividade poética e da 
potencialidade de ser. Algo que, tal como a simbologia da nuvem, associa-se à ideia da constante mudança e faz com que "o pássaro feito de homem" rompa metafórica e metafisicamente com o eixo da realidade e atinja o insólito, o maravilhoso, metamorfoseando-se em poesia, em poesia-nuvem.

Partindo disto, a busca pela Eternidade faria com que o ato da criação poética assumisse ares de resistência, pois é resistindo ao mundo entediante e metamorfoseando-o que o eu-lírico procura ressignificálo e ultrapassá-lo, almejando a unidade e a totalidade das coisas. Em prefácio a uma das edições dAs metamorfoses, o estudioso Fábio de Souza Andrade diz que, no livro,

Poeta e poema abrem-se para o encontro do eu com o exterior na sua máxima abrangência e, neste esforço, reúnem coisas e seres do mundo em casamentos inesperados: céu e terra, ar e mar. No entanto, por melhor realizada que seja, esta unidade almejada é sempre frágil, instável, e ameaçada pelo colapso iminente destas visões de harmonia nos enfrentamentos com a história contemporânea. [...] a lírica de Murilo Mendes se arma como poesia de resistência, o papel que Ihe cabe em meio a um mundo hostil (ANDRADE, 2002, p. 16).

Esta resistente empresa, que procura a totalidade das coisas associa-se, pelo menos a duas ideias: i) a (re)ligação do Eu com a essência do mundo e ii) as relações entre Eros e Liberdade. A primeira faz-nos refletir acerca da própria produção poética de cunho religioso, tema do qual Murilo Mendes é um dos maiores representantes brasileiros e ao qual também se aproxima A divina comédia, nomeada por alguns como "poema sacro" e ao que se deve a noção cristã moderna de Inferno e Paraíso, por exemplo. A própria etimologia da palavra religião leva-nos ao latim religare. Com isso, podemos associar Andrade e Bosi, pois, para este último, "Murilo é poeta de aderência ao ser, poeta cósmico e social que aceita a fruição dos valores primordiais. [...] Místico, ele perfura a crosta das instituições e dos costumes culturais para morder o cerne da linguagem religiosa, que é sempre a ligação do homem com a totalidade". (BOSI, 2017, p. 478).

Tendo em vista o princípio de união que parece mover os versos de Mendes em direção à tentativa de satisfação do desejo de alcançar a totalidade, cabe-nos novamente trazer Alfredo Bosi e sua proposição de que "Nos seus livros principais, A poesia em Pânico, As Metamorfoses e Poesia-Liberdade, Murilo Mendes objetiva a sua perplexidade em face de um mundo desconjuntado (sempre a obsessão do caos), que deve, porém, resgatar-se em vista dos valores absolutos: Eros e Liberdade" (BOSI, 2017, p. 480). Eros, princípio unificador e organizador do Caos, teria dado origem ao mundo, conforme a mitologia grega. Do mesmo modo, a partir de elementos como destruição e criação, Murilo Mendes empreende, liricamente, uma jornada ao modo de Dante. Uma jornada libertadora que concilia, nos dois livros em que se divide As metamorfoses e nos mais de cem poemas que lhe são constituintes, elementos dos mais diversos como a metáfora da reintegração com o Uno, o (re)conhecimento de si, o fazer poético como resistência e o equilíbrio entre Caos originário e Eros organizador.

\section{Cansar-se do mundo como aproximação}


Após esta abordagem de maneira mais ampla acerca das possíveis relações entre a poética de As metamorfoses (2002) e A divina comédia (2017), centremo-nos em dois poemas murilianos: "Fim" e "A chave", onde talvez possamos notar as ideias de insaciabilidade, do desejo de ir além, da falibilidade e finitude do mundo exterior ao eu-lírico etc. (ideias que podem ser resultantes de um cansaço) e seus contatos com a épica de Alighieri. O mundo tornou-se esgotável e esgotante para o eu-lírico, seja ele dantesco ou muriliano, e a ficção, o ensimesmar-se poético são as únicas vias de escape. A arte é a salvação e os versos, épicos ou líricos, são os únicos que oferecem as mãos para seres prestes a afogarem-se em seus mundos, seja no século XX ou nos séculos XIII e XIV. O mundo conhecido é pouco para os desejos de Alighieri e de Mendes. Para um cabe a inigualável conquista de tornar-se atemporal. Para outro cabe encontrar a salvação no passado, no retorno à tradição e na transfiguração do agora. Cansando-se do mundo, os poetas salvam outros poetas. Vejamos, pois, mais detidamente, como é a viagem espaço-temporal empreendida pelo poeta mineiro aos versos italianos.

\section{Fim}

Eu existo para assistir ao fim do mundo.

Não há outro espetáculo que me invoque.

Será uma festa prodigiosa, a única festa.

Ó meus amigos e comunicantes,

Tudo o que acontece desde o princípio é a sua preparação.

Eu preciso presto assistir ao fim do mundo

Para saber o que Deus quer comigo e com todos

E para saciar minha sede de teatro

Preciso assistir ao julgamento universal,

Ouvir os coros imensos,

As lamentações e as queixas de todos,

Desde Adão até o último homem.

Eu existo para assistir ao fim do mundo,

Eu existo para a visão beatífica

(MENDES, 2002, p. 56).

Ao iniciar o poema usando a primeira pessoa, o eu-lírico muriliano estabelece imediatamente uma espécie de restrição, de estratificação. 0 que se diz nos versos faz referência não ao leitor em si, mas ao próprio eu-poético. O uso do pronome pessoal da primeira pessoa do singular no caso de verbos conjugados no presente do indicativo é redundante. A desinência de número-pessoa "o" já marcaria que ali existiria um eu oculto. No entanto, o poeta o utiliza e isto pode ser tido como uma maneira de se acentuar a ideia de individualidade, de egocentrismo. A própria produção poética passa a ser vista como uma maneira que o eucriador encontrou para se satisfazer (?) da necessidade/falta de algo. Pode-se pensar, com isso, que o fazer artístico é tomado como uma tentativa do eu de se salvar. É interessante o uso do eu, pois o próprio Dante usa a primeira pessoa em A Divina Comédia, algo que foi novo e muito importante nos poemas épicos, pois aproximou o leitor da experiência narrada/vivida. 
O uso do pronome possessivo, no verso "Ó meus amigos e comunicantes", reforça a ideia do comentário sobre a primeira pessoa, isto é, distancia-se o leitor do eu-lírico e os acontecimentos poetizados se restringem a este. No grande espetáculo que é a vida, segundo o poeta, parece que os outros, os leitores são meros espectadores. Mas tal distância, no ato de leitura, acaba por se revelar como algo compartilhado, pois o leitor, apesar de não viver o que é dito, acaba por encarnar o eu-enunciativo e torna-se, então, uma espécie de (co)autor e complementa o sentido do texto, algo que tange o pensamento bakhtiniano. Complementa no sentido de que faz acontecer, vive e, mesmo que não sejam suas as experiências versadas, pode vir a reconhecer-se (catarse) nelas e delas compartilhar os mesmos sentimentos. Ainda no âmbito mais estrutural, por assim dizer, do poema, note-se que o uso de verbos no presente pode vir a denotar uma universalidade dos acontecimentos. Com efeito, o clamor, a angústia e a insaciabilidade do eu-lírico seriam eternamente presentes.

O uso de expressões como "festa", "teatro" e "espetáculo" pode se associar à noção da vida como uma grande farsa, algo velado. Pensemos, pois, numa relação platônica, a julgar pela ideia de que aquilo que se presencia é meramente uma projeção de um mundo superior, ideal, verdadeiro. A teatralidade da existência pode ser vista, pois, como a própria consciência da finitude do mundo e do fado da insaciabilidade. Cabe-nos notar, também, a possível angústia, que provém do desejo de "saber o que Deus quer" com ele próprio e com todos os outros, que se acerca do eu-lírico, numa busca de sentido para a vida. O sentido encontrar-se-ia em Deus, na visão do divino. Assim como em Dante, a plenitude da seidade seria alcançada com a visão de Deus. Ainda sobre a teatralidade aparente, vale a pena ressaltar a influência do Barroco espanhol para a produção de Murilo Mendes, segundo traz Pereira (2009). Consoante ela, no Barroco espanhol, as ideias de mundo e teatro poderiam ser resumidas em fórmulas como "o mundo é um teatro" ou "a vida é sonho", que retomam um dos pontos de abordagem de "Fim".

Algumas expressões do poema remetem-nos aos três ambientes dantescos. O Inferno de Dante é um local essencialmente dorido e o que reforça tal pena é sua intransitividade. Ou seja, não há saída, não há esperança. "Deixai, ó vós que entrais, toda a esperança” (ALIGHIERI, 2017, p. 27 [Inf., canto III, v. 9]), diz a escritura em sua porta. Consequentemente, muitas almas condenadas erguem queixas ao divino. $\mathrm{O}$ eu-lírico de "Fim" demonstra o desejo de assistir ao fim do mundo e, com efeito, presenciar o Julgamento Final e ouvir as queixas de todos. Estas podem ser associadas àquelas enunciadas pelos pecadores no Inferno de Dante. É como se o eu-lírico muriliano desejasse vivenciar de uma só vez os Inferno, Purgatório e Paraíso dantescos. O primeiro, como foi dito, seria representado pelo desejo de ouvir as queixas, os dois últimos seriam representados pela escuta das lamentações (provenientes, quiçá, dos pecados sendo purgados) e dos coros imensos (tais quais existem no Paraíso, que é todo luz e cânticos).

Um dos aspectos mais pontuais entre "Fim" e A Divina Comédia é a ideia da "visão beatífica". Ora, esta pode ser vista como a visão da própria Beatriz dantesca ou como a visão daquilo que Beatriz o revelaria, pois o nome desta significa "aquela que confere beatitude", segundo Sterzi (2008, p. 31). A partir disso, podemos tratar de "A chave", onde Mendes revela novamente seu espírito insaciável e seu desejo de 
procura, algo que, como já foi dito, é também muito presente em Dante, a julgar pelas ideias da jornada como sendo i) uma busca por amor (tendo em vista o sentimento do eu-empírico de Dante por Beatriz), ii) por autoconhecimento, iii) por Deus etc.

\author{
A chave \\ Onde estás eternidade \\ Nasci para te encontrar \\ Habituei-me à minha forma \\ Já estou cansado de me ver \\ Estou cansado de me interrogar \\ De decifrar as mesmas cores \\ E de acolher os mesmos sons \\ Quero os novos elementos. \\ Onde estás eternidade \\ (MENDES, 2002, p. 116).
}

Ao revelar sua insatisfação, seu enfado em se questionar, seu cansaço "De decifrar as mesmas cores/ E de acolher os mesmos sons", o eu-lírico transparece um sentimento próximo ao tédio, pois o mundo assemelha-se a algo que perdeu o sentido. $O$ que se revela em seus versos é a mesmice do mundo, a perda do aspecto de novidade. Com efeito, são expressos desejos de querer "os novos elementos", a "eternidade". O Eterno seria aquilo essencialmente pleno, que ressignificaria o conhecido e, por ser pleno em si, anularia as carências do Ser.

Diante disso, a poesia de Murilo Mendes refletiria um modo de se olhar para a finitude do homem, para a inevitável mesmice do mundo e a busca por uma reação. Dentre as possíveis atitudes, pode-se pensar numa entrega absoluta, um mergulho no tédio cotidiano e na consciência do nada. Entretanto, tais reações estariam ligadas à noção de passividade. Ou seja, o eu-lírico teria consciência do nada que o cerca, mas sofreria ainda mais do que antes, pois o fato de não ignorar os motivos do sofrer escancaram a incapacidade de se agir efetivamente em busca de ultrapassá-los ${ }^{5}$; Os motivos seriam conhecidos, mas nada se faria para mitigá-los. Ou ainda, numa visão ao que parece muito mais próxima daquela presente no poema, saber-seia da finitude do mundo e o eu-lírico se apresentaria como aquele que já não se sacia com o mundo exterior, aquele para quem tudo é o "mesmo". Consequentemente, este não o satisfaria e ele buscaria algo maior, que não se conheça o fim, o próprio Uno, o abstrato Eterno. Associando os modos de vê-lo como um poeta das possibilidades, pai de uma poesia-nuvem, podemos dizer que, assim como Dante, Murilo Mendes busca, nos versos de As metamorfoses, a fonte e a conclusão de tudo: Deus.

\footnotetext{
${ }^{5}$ C.f. SVENDSEN, Lars. Filosofia do tédio. Tradução Maria Luiza X. de A. Borges. Rio de Janeiro: Jorge Zahar, 2006.
} 


\section{Considerações finais}

Podemos perceber que as ressonâncias de $A$ divina comédia em As metamorfoses beiram as noções da absorção e aquela se mostra nesta última de maneira diluída. É nas entranhas murilianas que as essências da obra-prima de Dante Alighieri tornam-se visíveis. Mesmo sem citações ou referências explicitamente evidentes, a influência de Dante dá-se no modo de enxergar o mundo e desejar buscar algo além, fugir da mesmice cotidiana e pleitear a Unidade das coisas. Destaquemos que, se tivermos conseguido apresentar análises dignas de confiança e plausibilidade, a temática não esgota, nem foi esse o objetivo do presente escrito. Podem-se desenvolver diversos estudos sobre o assunto, seja comparando outras obras de Murilo Mendes com A divina comédia, cotejando o próprio As metamorfoses com o escrito de Dante ou então apontando muitos outros pontos de contato entre a épica dantesca e distintos textos nacionais de diferentes épocas e estilos.

\section{Referências bibliográficas}

AGAMBEN, Giorgio. O que é o contemporâneo? In: . 0 que é o contemporâneo? e outros ensaios. Trad. Vinicius Nicastro Honesko. Chapecó/SC: Argos, 2009. p. 55-73.

ALIGHIERI, Dante. A divina comédia. 12. ed. Tradução Xavier Pinheiro. Rio de Janeiro: Nova Fronteira, 2017. ANDRADE, Fábio de Souza. Prefácio. In: MENDES, Murilo. As metamorfoses. Rio de Janeiro: Record, 2002. p. 11-17.

BOSI, Alfredo. Murilo Mendes. In: . História concisa da literatura brasileira. 52. ed. São Paulo: Cultrix, 2017. p. 477-482.

CANDIDO, Antônio. Pastor pianista/pianista pastor. In: São Paulo: Ática, 1985. p. 81-95. . Na sala de aula: caderno de análise literária.

CARPEAUX, Otto Maria. Lendo e relendo Dante. In: ALIGHIERI, Dante. A divina comédia. 12. ed. Tradução Xavier Pinheiro. Rio de Janeiro: Nova Fronteira, 2017. p. 5-14.

CARVALHAL, Tânia Franco. Literatura comparada. 3. ed. São Paulo: Ática, 1986.

CHEVALIER, Jean; GHEERBRANT, Alain. Nuvem. In: Dicionário de símbolos: mitos, sonhos, costumes [...]. rev. atual. Colaboração André Barbault et al. Coordenação Carlos Sussekind. Tradução Vera da Costa e Silva et al. Rio de Janeiro: José Olympio, 1988. p. 648.

COMBE, Dominique. A referência desdobrada: o sujeito lírico entre a fiç̧ão e a autobiografia. Tradução Iside Mesquita e Vagner Camilo. Revista USP, São Paulo, n. 84, p. 112-128, Dez./Fev. 2009-2010.

LUCCHESI, Marco. Nove cartas sobre a divina comédia: navegações pela obra clássica de Dante. Rio de Janeiro: Casa da palavra, 2013.

MOISÉS, Massaud. Espécies poéticas: o lírico e o épico. In: . A criação literária: poesia e prosa. rev. atual. São Paulo: Cultrix, 2012. p. 188-215.

MENDES, Murilo. As metamorfoses. Rio de Janeiro: Record, 2002.

NITRINI, Sandra. Literatura comparada: história, teoria e crítica. 3. ed. 1. reimpr. São Paulo: Editora da Universidade de São Paulo, 2015. 
PEREIRA, Eva. "A carne inconformada": notas para uma aproximação entre Poesia e Metafísica em Murilo Mendes. In: MELLO, Ana Maria Lisboa de. (Org.). A poesia metafísica no Brasil: percursos e modulações. Porto Alegre: Libretos; FAPA - Faculdade Porto Alegrense, 2009. p. 247-276.

PLOTINO. Tratado das Enéadas. Tradução Américo Sommerman. São Paulo: Polar Editorial, 2000.

SANTOS, J. V. R. Mitologia e realidade em Poemas gregos (1985): deuses caídos, cabisbaixos e humildes? In: Travessias interativas. São Cristóvão: Universidade Federal de Sergipe, v. 9, n. 18, p. 81-94, Maio 2019.

STERZI, Eduardo. Por que ler Dante. São Paulo: Globo, 2008.

SVENDSEN, Lars. Filosofia do tédio. Tradução Maria Luiza X. de A. Borges. Rio de Janeiro: Jorge Zahar, 2006. 